\title{
Transplanted olfactory ensheathing cells restore retinal function in a rat model of light-induced retinal damage by inhibiting oxidative stress
}

\author{
Langyue Xue ${ }^{1,2}$, Yuxiao Zeng ${ }^{1,2}$, Qiyou Li ${ }^{1,2}$, Yijian $\mathrm{Li}^{1,2}$, Zhengya $\mathrm{Li}^{1,2}$, Haiwei $\mathrm{Xu}^{1,2}$ \\ and Zhengqin Yin ${ }^{1,2}$ \\ ${ }^{1}$ Southwest Hospital/Southwest Eye Hospital, Third Military Medical University, Chongqing 400038, China \\ ${ }^{2}$ Key Lab of Visual Damage and Regeneration \& Restoration of Chongqing, Chongqing 400038, China \\ Correspondence to: Haiwei Xu, email: haiweixu2001@163.com \\ Zhengqin Yin, email: qinzyin@aliyun.com \\ Keywords: light damage, photoreceptor, olfactory ensheathing cells, reactive oxygen species \\ Received: March 28, $2017 \quad$ Accepted: August 08, $2017 \quad$ Published: October 16, 2017 \\ Copyright: Xue et al. This is an open-access article distributed under the terms of the Creative Commons Attribution License 3.0 \\ (CC BY 3.0), which permits unrestricted use, distribution, and reproduction in any medium, provided the original author and source \\ are credited.
}

\section{ABSTRACT}

There is still not an effective treatment for continuous retinal light exposure and subsequent photoreceptor degeneration. Olfactory ensheathing cell (OEC) transplantation has been shown to be neuroprotective in spinal cord, and optic nerve injury and retinitis pigmentosa. However, whether OECs protect rat photoreceptors against light-induced damage and how this may work is unclear. Thus, to elucidate this mechanism, purified rat OECs were grafted into the subretinal space of a LongEvans rat model with light-induced photoreceptor damage. Light exposure decreased a- and b- wave amplitudes and outer nuclear layer (ONL) thickness, whereas the ONL of rats exposed to light for $24 \mathrm{~h}$ after having received OEC transplants in their subretinal space was thicker than the PBS control and untreated groups. A- and bwave amplitudes from electroretinogram of OEC-transplanted rats were maintained until 8 weeks post OEC transplantation. Also, transplanted OECs inhibited formation of reactive oxygen species in retinas exposed to light. In vitro experiments showed that OECs had more total antioxidant capacity in a co-cultured $661 \mathrm{~W}$ photoreceptor cell line, and cells were protected from damage induced by hydrogen-peroxide. Thus, transplanted OECs preserved retinal structure and function in a rat model of lightinduced degeneration by suppressing retinal oxidative stress reactions.

\section{INTRODUCTION}

Continuous retinal light exposure may irreversibly damage photoreceptor cells [1], and this is a common eye insult $[2,3]$. Although the pathogenesis of light-induced retinal damage is unclear, several pathological changes, including elevated calcium ions [4], apoptosis, free radical production and lipid peroxidation-have been reported to be involved in irreversible retinal damage after exposure to intense light [5]. Currently, the main therapeutic methods for light-induced retinal damage involve treatment with calcium-channel-blockers [6], glucocorticosteroids [7], neurotrophic factors $[8,9]$, antioxidant and anti-lipid peroxidation treatment $[10,11]$, but their effects are not satisfactory.

Olfactory ensheathing cells (OECs) are a special group of glial cells that reside in the olfactory system and support neurogenesis throughout a person's life time [12]. These cells share some characteristics with Schwann cells and astrocytes. Like astrocytes, OECs express glial fibrillary acidic proteins (GFAP) in their cytoskeleton, but they share similar morphological and molecular markers with Schwann cells [13-16]. OECs may secrete various neurotrophic factors, including nerve growth factors (NGFs), brain derived neurotrophic factors (BDNFs), glial cell line-derived neurotrophic 
factors (GDNFs), ciliary neurotrophic factors (CNTFs) and vascular endothelial growth factors (VEGFs). Also, OECs express proteins such as S-100, nerve growth factor receptor p75 (NGFR p75), neural cell adhesion molecule (N-CAM) and laminin, all of which contribute to the development of neurons $[15,17]$. Recent studies indicate that grafted OECs rearranged glial scars in CNS and provided tunnels for the regeneration of axons after adult mammals spinal cord injury [18, 19]. Transplantation of OECs into CNS lesion induced axonal regeneration and neural functional recovery [14, 20-27]. OECs can enter fibroblast zones to promote neurite outgrowth in growth-inhibitory areas in the multicellular scar-like culture model [28]. More effective axon regeneration and functional recovery of the CNS are usually achieved via transplantation of genetically engineered OECs [29]. It has also reported that OECs improve local microcirculation of the damaged spinal cord and promote angiogenesis, thus enhancing remyelination of demyelinated neuronal axons [30, 31]. According to previous work, OECs transplantation is clinically safe $[32,33]$ and offers promising therapeutic outcomes for patients [34].

In the visual system, grafted OECs promote regeneration of retinal axons of ganglion cells in adult rats with optic nerve crush [35]. OECs are incorporated into the optic nerve head after transplantation into the retina of the retrobulbar optic nerve after axotomy in rat models [36]. Leaver's group [37] reported that OECs could support the regrowth of retinal ganglion cell neurites in vitro. Our previous results indicated that grafted OECs in the subretinal space of Royal College of Surgeons (RCS) rats migrated through all layers of the retina and suppressed gliosis formation by the over-activation of Müller cells [38]. We found also that purified OECs inhibited activation of Müller cells by suppressing the Notch pathway, thus protecting photoreceptors in RCS rats [39].

Thus, grafted OECs could protect recoverin-positive photoreceptor cells and delay retinal degeneration [40]. However, whether OECs also protect against light-induced retinal damage and its mechanisms is unknown. Therefore, we used a rat model with light-induced retinal damage to explore the effect of grafted OECs on retinal light damage. Then, we used $661 \mathrm{~W}$ photoreceptor cells to investigate the ability of OECs to protect against oxidative stressinduced damage and attempted to elucidate the underlying mechanism.

\section{RESULTS}

\section{Effect of light exposure on retinal morphology and function in Long-Evans rats}

To evaluate the effect of light exposure on the retina, electroretinogram (ERG) recording and hematoxylin and eosin (H\&E) staining were performed one day after light exposure. H\&E staining showed that the organized structure of retina in unexposed rats was intact (Figure 1A). After $12 \mathrm{~h}$ of light exposure, cells in the ONL of the retina were irregularly arranged, and few had hyperchromatic nuclei (Figure 1B). Twenty-four hours of light exposure caused more pyknotic nuclei, intercellular space dilatation and disordered-arrangement of ONL cells (Figure 1C). After $36 \mathrm{~h}$ of light exposure, the structure of ONL was more disordered, and most of the nuclei in the ONL become karyolytic and detached (Figure 1D). Simultaneously, the scotopic ERG amplitude decreased in the light-damaged groups. Compared with controls, the amplitude decreased by more than $80 \%$ in groups exposed to light for both 12 and $24 \mathrm{~h}$. In particular, in the group exposed to light for $36 \mathrm{~h}$, the amplitude was significantly diminished (Figure 1E and $1 \mathrm{~F}$ ). Thus, rats exposed to light for $24 \mathrm{~h}$ were selected for subsequent cell transplantation experiments.

\section{Isolation of OECs and protection of light- exposed retinas}

After two weeks, primary cultured OECs grew tightly packed in fusiform or spindle forms (Figure 2A). S100- positive OECs were characterized by primarily fusiform or spindle forms, while fibronectin (FN)-positive olfactory nerve fibroblasts (ONFs) had diverse forms (Figure 2B). After purification, approximately $90 \%$ of cells were S100-positive OECs.

Eight weeks post-transplantation, CellTracker CMDiI-labeled cells spread in the subretinal space (Figure 2C). The ONL of the temporal retina in the light-induced retinal damage group gradually thinned over time after light exposure (Figure 2D-2M). At 2, 4, and 8 weeks, the ONL thickness for every $0.5 \mathrm{~mm}$ intervals in the OEC group was significantly thicker than that in the PBS and untreated groups in the temporal retina (the injection region) and the nasal retina (Figure $2 \mathrm{~N}-2 \mathrm{P}$ ).

\section{Transplanted OECs and ERG recording of light exposure-induced retinal degeneration}

After light damage, a- and b-wave amplitudes of the untreated group decreased over time (Figure 3A). At 2 weeks, all groups had attenuation, but the amplitude of the OEC group was significantly different compared to all other groups, $(p<0.01)$ (Figure 3B and 3C). Four weeks after treatment, the amplitude of the OECs and PBS groups mildly rebounded, but the OEC group recovered more significantly, with significant differences $(p<0.01)$ compared to PBS and untreated groups (Figure 3B and 3C). At 8 weeks, amplitudes decreased in each group. However, the OEC group was significantly different compared to the untreated and PBS groups $(p<0.01)$ (Figure $3 \mathrm{~B}$ and $3 \mathrm{C}$ ). These results suggested that OEC 
transplantation improved visual function of degenerative retinas. Thus transplanted OECs delayed light exposureinduced photoreceptor degeneration.

\section{Effect of grafted OECs on reactive oxygen species (ROS) in light exposure-induced damaged retinas}

ROS immunofluorescent staining showed that light damage produced peroxide in the retina (Figure 4A-4I). At 2 weeks, compared with PBS and untreated groups, peroxide labelling by 2', 7'-dichlorofluorescein diacetate (DCFH-DA) in the retina of the OEC transplanted group had decreased (Figure 4A-4C and 4J) $(p<0.05)$. After 4 weeks, peroxide produced in the retina of all groups was decreased, but labeled peroxide in the OEC transplanted group was the lowest of all groups (Figure 4D-4F and 4J) $(p<0.05)$. After 8 weeks, the groups were not significantly different (Figure 4G-4I and 4J). Transplanted OECs thus could inhibit oxidative stress in the retina which was protective.

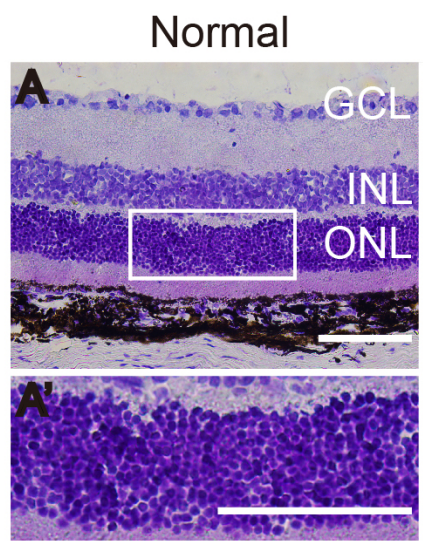

E
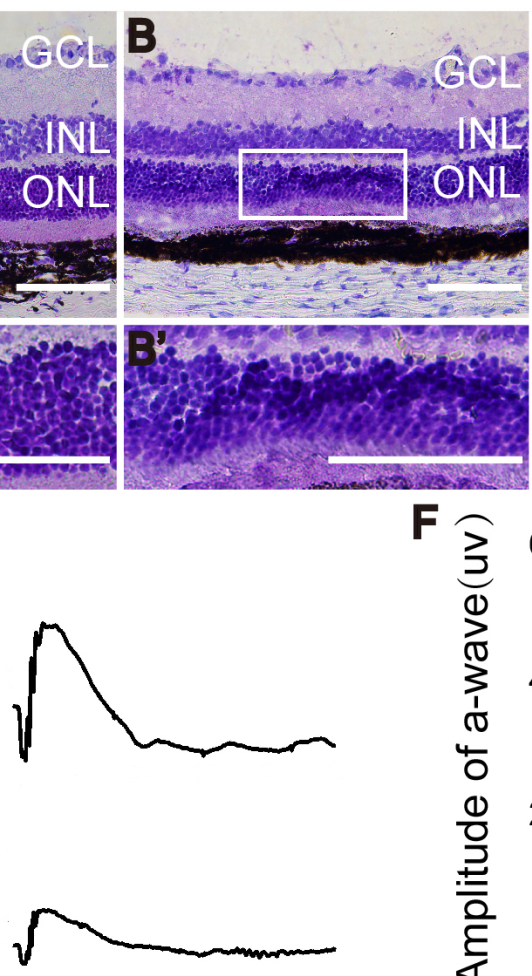

$\mathbf{F}$

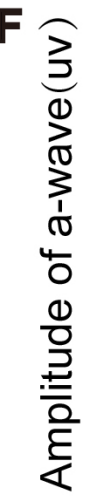
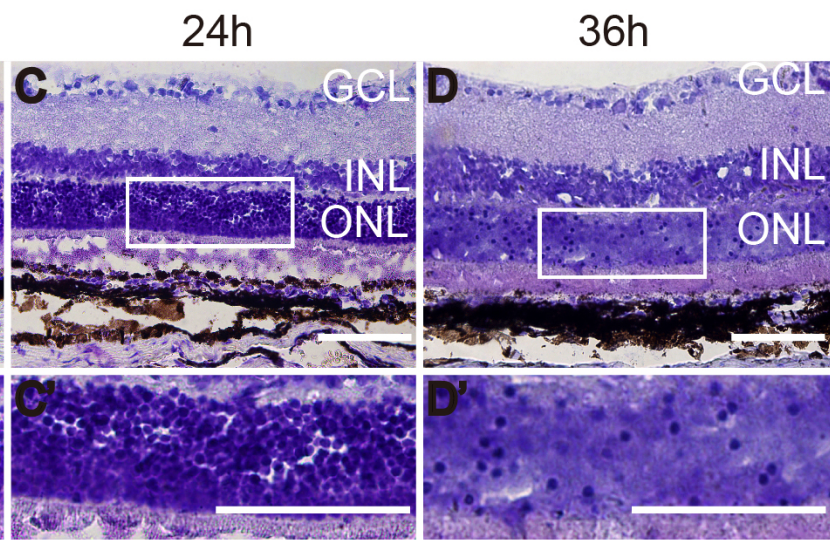

$12 \mathrm{~h}$

$24 \mathrm{~h}$

$36 \mathrm{~h}$

Normal
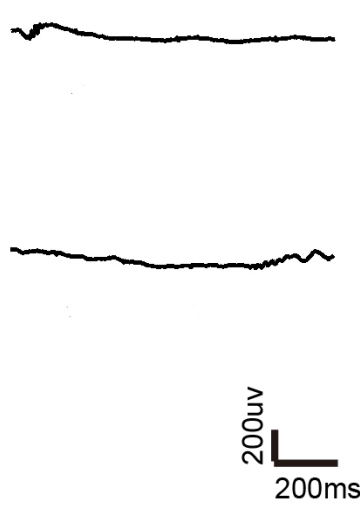

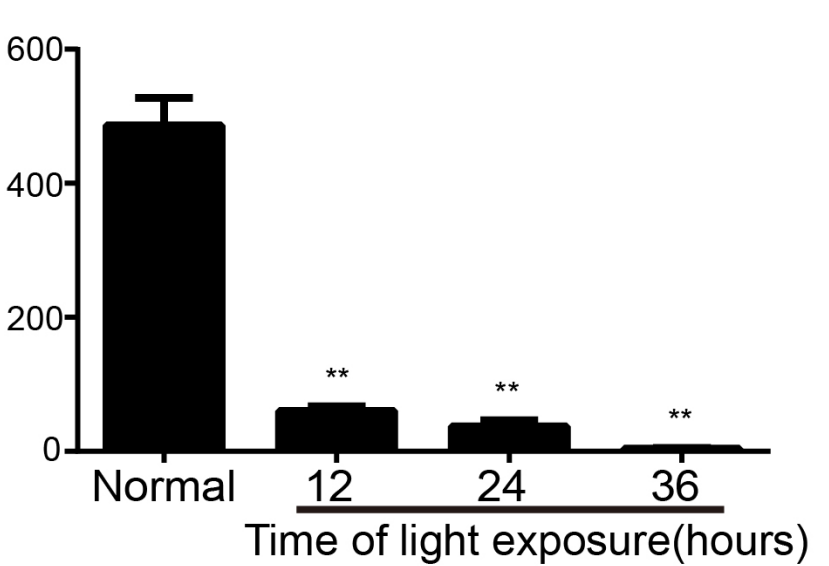

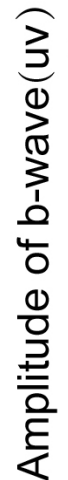

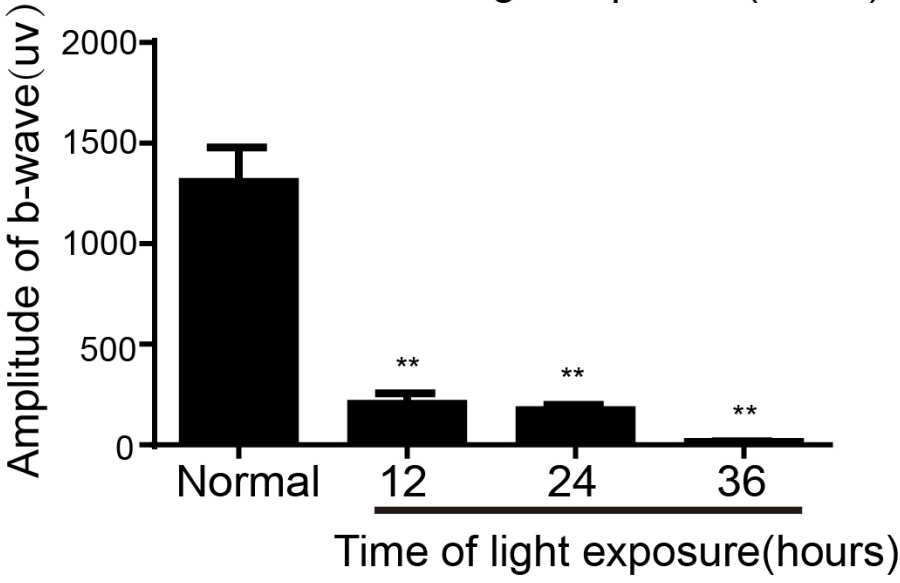

Figure 1: Effect of light exposure on retinal morphology and function in LE rats. (A-D) Morphological changes of retina after different times of light exposure. (E) ERG traces recorded after different time of light exposure. (F) Amplitudes of a- and b-wave.GCL, ganglion cell layer; INL, inner nuclear layer; ONL, outer nuclear layer. Scale bars, $100 \mu \mathrm{m} . \mathrm{n}=5,{ }^{* *}, p<0.01$. 

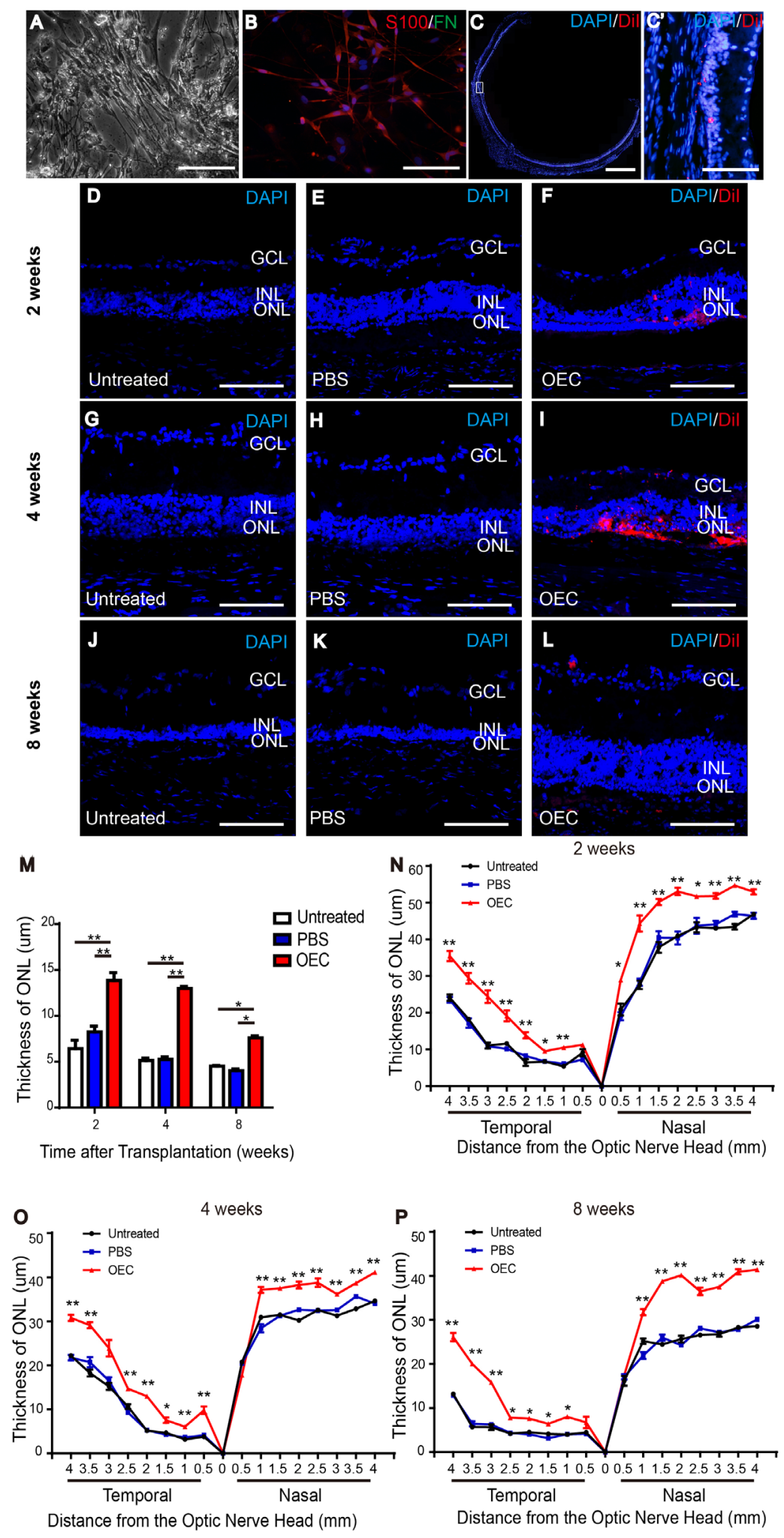

Figure 2: Characterization of OECs and protection of the ONL of light-damaged retinas of LE rats. (A) Fusiform cells and flattened cells. (B) Representative images of OECs stained with S100 (red), fibronectin (green) and DAPI (blue). (C) Spread of the transplanted cells (red) in the subretinal space around the injection site. (D, G, J) Untreated rat at 2 weeks (D), 4 weeks (G) and 8 weeks (J). (E, H, K) PBS injection at 2 weeks (E), 4 weeks (H) and 8 weeks (K). (F, K, L) Retina with transplanted OECs at 2 weeks (F), 4 weeks (K) and 8 weeks (L). (M) Thickness of ONL in the temporal region $2 \mathrm{~mm}$ to the optic nerve head. (N-P) ONL thickness in the temporal and nasal regions of retina. Counterstained DAPI, blue; transplanted cells CM-DiI, red. Scale bars, $100 \mu \mathrm{m}$ (A, B, C'-L), $1000 \mathrm{um}(\mathrm{C}) . \mathrm{n}=3,{ }^{*}$, $p<0.05,{ }^{* *}, p<0.01$. 


\section{Co-culture with purified OECs protects $661 \mathrm{~W}$ from damage induced $\mathrm{byH}_{2} \mathrm{O}_{2}$}

5-ethynyl-20-deoxyuridine (EdU) and Ki67 staining showed that $\mathrm{H}_{2} \mathrm{O}_{2}$ exposure affected the proliferation rate of $661 \mathrm{~W}$ cells. After exposure to $0.5 \mathrm{mM} \mathrm{H}_{2} \mathrm{O}_{2}$ for $30 \mathrm{~min}$, EdU and Ki67 positive cells significantly decreased, with then co-culturing of the OECs for $24 \mathrm{~h}$ mitigating the impacts of $\mathrm{H}_{2} \mathrm{O}_{2}$ (Figure 5A-5H). CCK-8 assay analysis indicated that the viability of $661 \mathrm{~W}$ cells decreased approximately $50 \%$ after $\mathrm{H}_{2} \mathrm{O}_{2}$ exposure. However, coculture with OECs for $24 \mathrm{~h}$ reduced damage to $661 \mathrm{~W}$ cells induced by $\mathrm{H}_{2} \mathrm{O}_{2}$ (Figure 5I).

\section{Co-culture with OECs can mitigate apoptosis induced by $\mathrm{H}_{2} \mathrm{O}_{2}$}

Exposure to $\mathrm{H}_{2} \mathrm{O}_{2}$ can increase TdT-Mediated dUTPNick End Labeling (TUNEL) positive cells, and co-culture with OECs diminish the proportion of them (Figure 6A-6C and 6G). Apoptosis of $661 \mathrm{~W}$ cells was measured by flow cytometry and early and late apoptosis increased after exposure to $\mathrm{H}_{2} \mathrm{O}_{2}$, but this was reduced with co-culture with OECs(Figure 6D-6F and 6H-6I).

\section{OECs reduced intracellular ROS elevation after $\mathrm{H}_{2} \mathrm{O}_{2}$ exposure}

$\mathrm{H}_{2} \mathrm{O}_{2}$-induced oxidative stress response can induce cellular injury, so we assayed co-cultured $661 \mathrm{~W}$ cells with DCFH-DA, and fluorescent intensity was quantified. Figure 7 showed that fluorescent intensity significantly increased in $661 \mathrm{~W}$ cells after exposure to $\mathrm{H}_{2} \mathrm{O}_{2}$ for 30 min. Compared to the $\mathrm{H}_{2} \mathrm{O}_{2}$-treated group, co-culture with OECs reduced the accumulation of intracellular ROS. Co-culturing with OECs increased cellular antioxidant defense (Figure 7I).

Real-time PCR (Figure 7J-7M) showed that the expression of NOX4 and iNOS were significantly increased and the expression of SOD1 and CAT were decreased in the cells with $\mathrm{H}_{2} \mathrm{O}_{2}$ treated. However, after co-cultured with OECs, the expression of NOX4 and
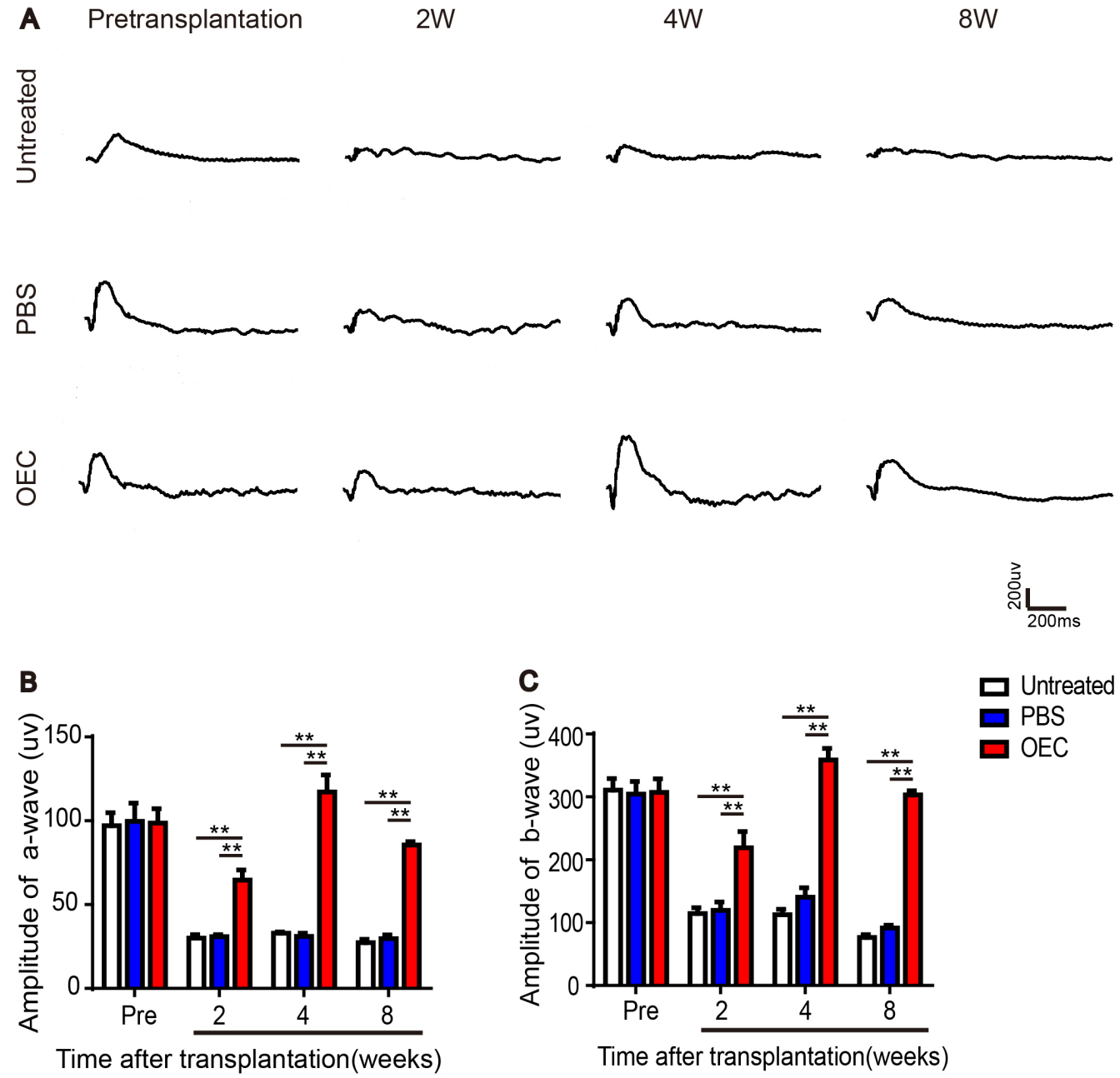

Figure 3: Transplanted OECs rescue ERG recordings of light exposure-induced retinal degeneration. (A) ERG traces after transplantation of OECs. (B) Amplitudes of a-wave. (C) Amplitudes of b-wave. $\mathrm{n}=6,{ }^{*}, p<0.05,{ }^{* *}, p<0.01$. 

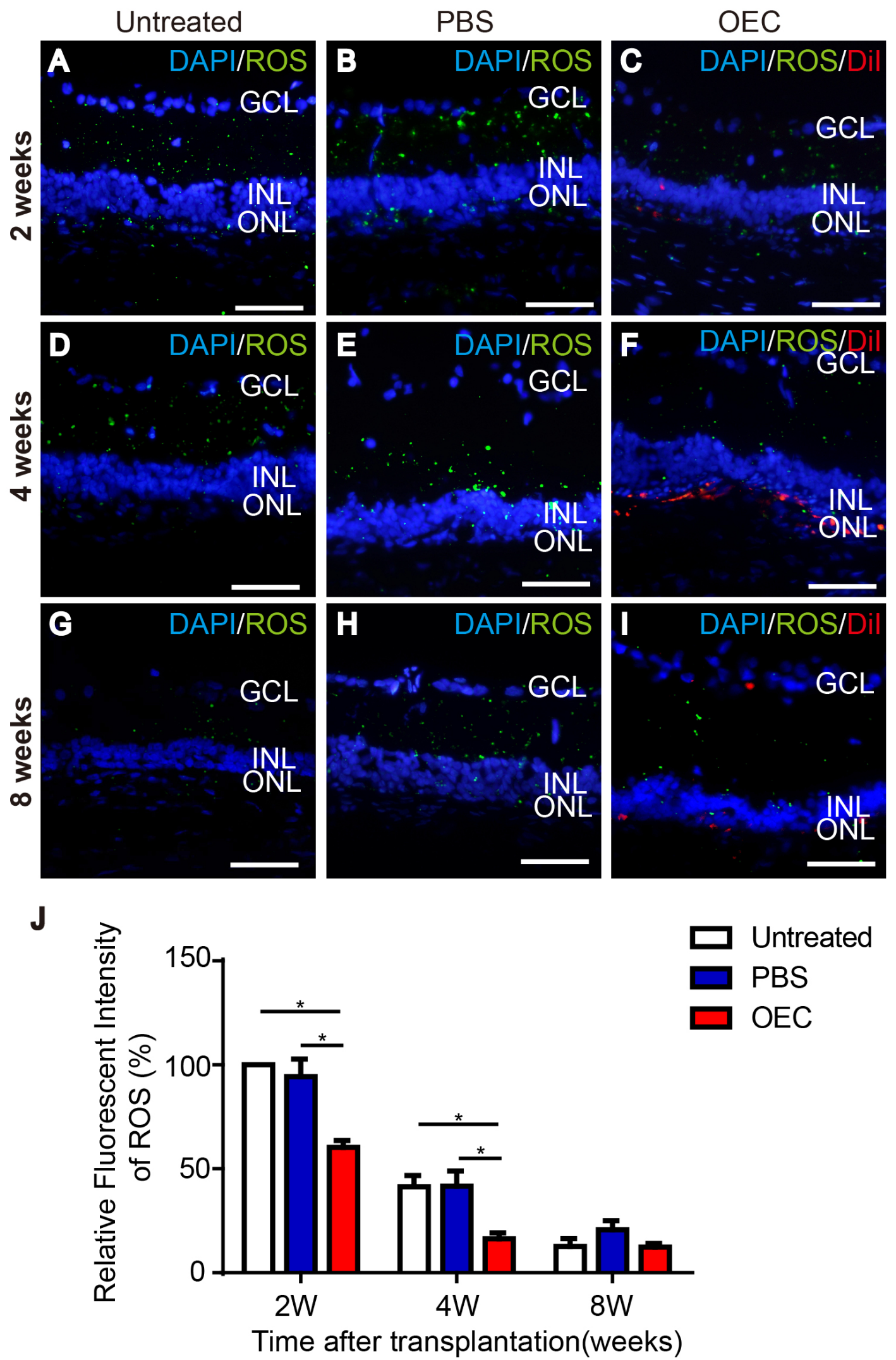

Figure 4: Effect of grafted OECs on the ROS level in light exposure-induced retina damage. (A, D, G) Untreated rat at 2 weeks (A), 4 weeks (D) and 8 weeks (G). (B, E, H) PBS injection at 2 weeks (B), 4 weeks (E) and 8 weeks (H). (C, F, I) Retina with transplanted OECs at 2 weeks (C), 4 weeks (F) and 8 weeks (I). (J) Relative fluorescent intensity of ROS. Transplanted cells, red; ROS, green; Counterstained DAPI, blue. Scale bars, $50 \mu \mathrm{m} . \mathrm{n}=3,{ }^{*}, \mathrm{p}<0.05$. 
iNOS were markedly lower than in $\mathrm{H}_{2} \mathrm{O}_{2}$ group, and the expression of SOD1 and CAT were higher than in $\mathrm{H}_{2} \mathrm{O}_{2}$ group. Western blots showed that in the $\mathrm{H}_{2} \mathrm{O}_{2}$ group, the protein content of NOX4 and iNOS in $\mathrm{H}_{2} \mathrm{O}_{2}$ group were the highest and SOD1 content were lowest among all the samples (Figure $7 \mathrm{~N}$ ). Our results suggested that reduction of intracellular ROS by transplanted OECs may be an important protective mechanism for light damaged photoreceptors.

\section{DISCUSSION}

In this study, we established a rat model for light-induced retinal degeneration according to published methods [41] and provided evidence (by immunofluorescent staining) that transplanting primary cultured OECs into the subretinal space might preserve both the retinal function and the ONL thickness in rats by mitigating retinal oxidative stress reactions with ERG. Our in vitro study confirmed that OECs could protect cells from $\mathrm{H}_{2} \mathrm{O}_{2}$-generated injury by alleviating the oxidative stress response.

A light stimulus signal triggers the visual transduction pathway by photoreceptors, but intense visible light can activate oxygen free radicals to damage the retina [2]. Retinal light-damage models have been used to study human retinal degenerative diseases caused by the environmental, age or genetic lesions, such as aged macular degeneration, in which retinal anatomical structural changes are similar to retinal cell remodelling during late stages of light damage in rodents [42-44]. Therefore, we used a light-induced retinal damage rat model. ERG can record animal retinal function, and this technique is used to observe the effect of experimental
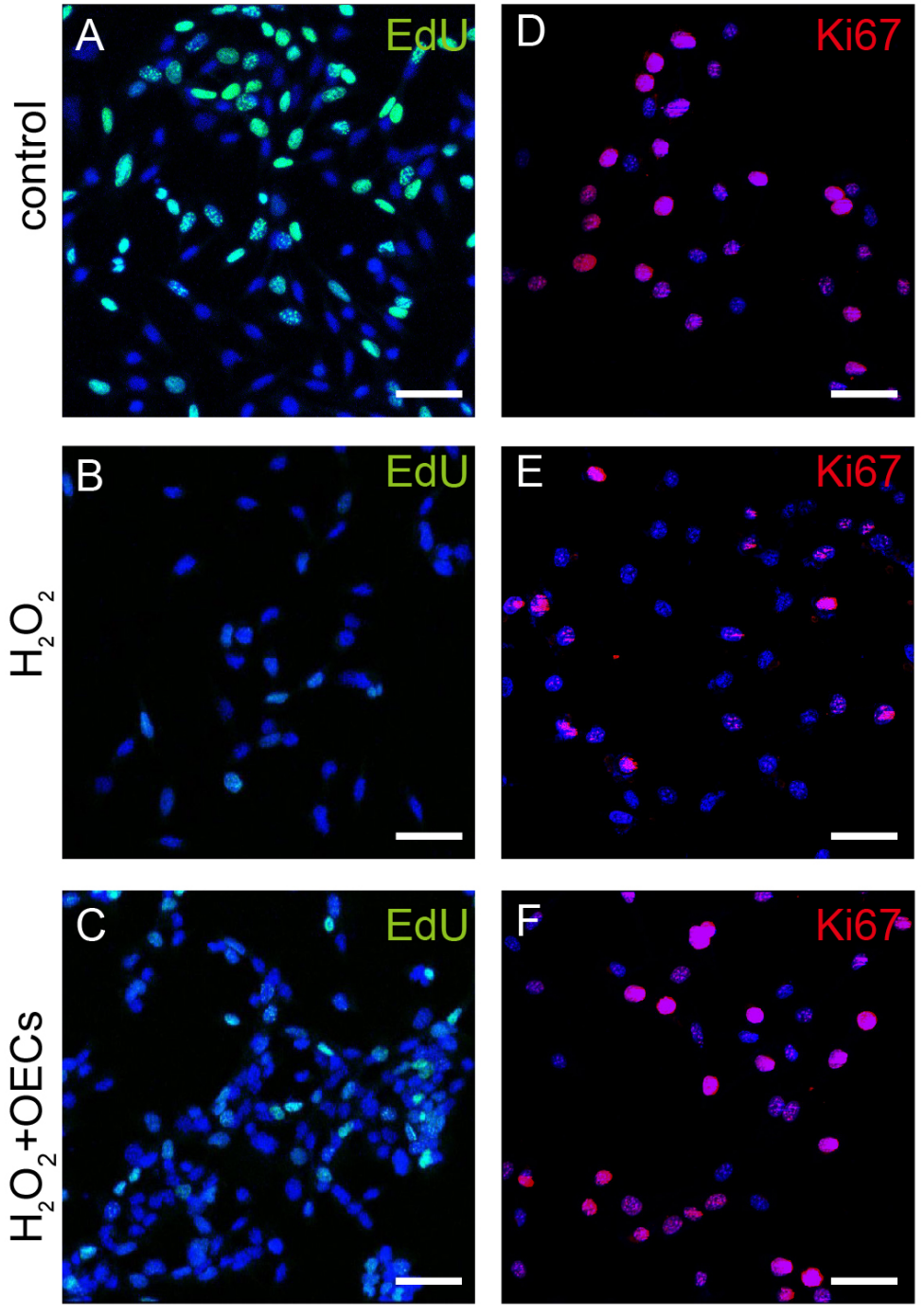
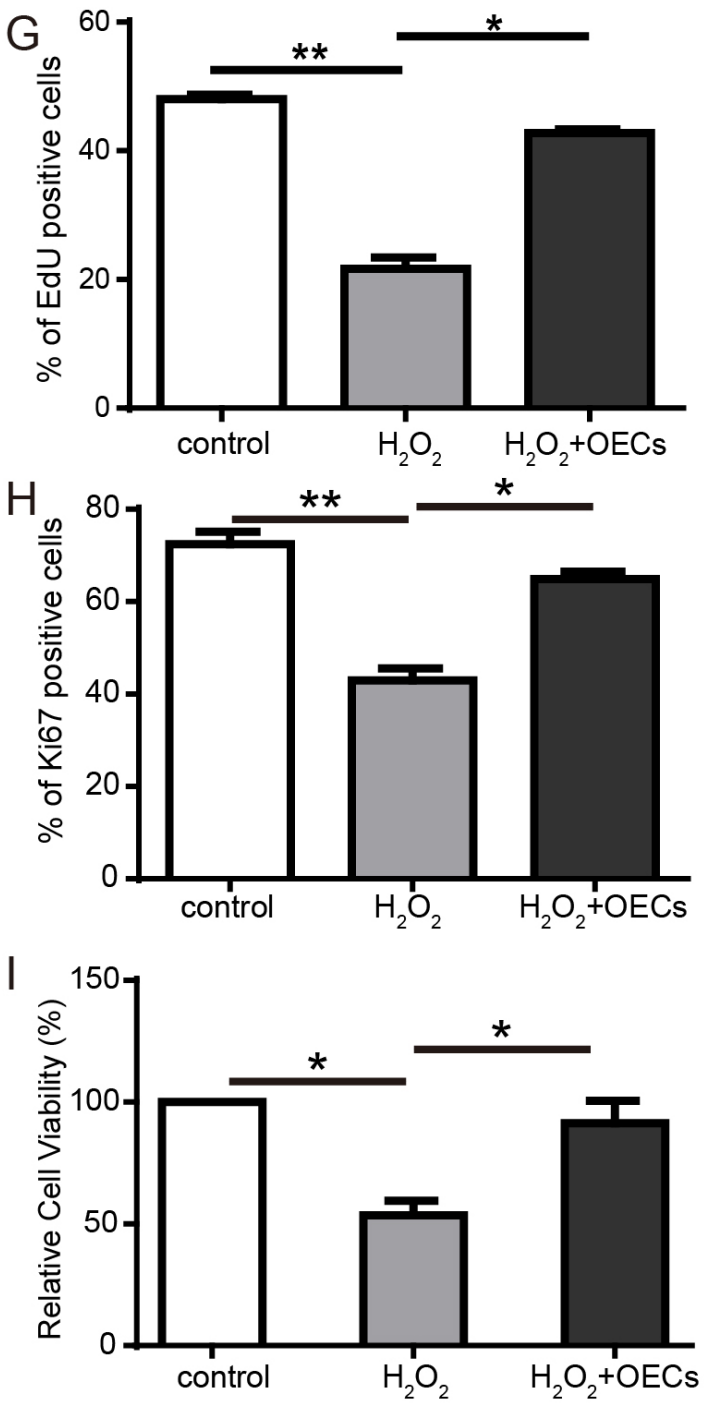

Figure 5: Co-cultured OECs protect $661 \mathrm{~W}$ from proliferation impairment induced by $\mathrm{H}_{2} \mathrm{O}_{2}$. (A-C and G) EdU labeling analysis of $661 \mathrm{~W}$ cells, $\mathrm{n}=3$. (D-F and $\mathbf{H}$ ) Ki67 staining of $661 \mathrm{~W}$ cells, $\mathrm{n}=3$. (I) CCK-8 assay analysis of $661 \mathrm{~W}$ cells, $\mathrm{n}=5$. Scale bars, 50 $\mu \mathrm{m} .{ }^{*}, \mathrm{p}<0.05,{ }^{* *}, \mathrm{p}<0.01$. 
factors on retinal function. We used ERG to confirm the degree of light-induced retinal damage. Because light exposure usually causes regional decline in ONL thickness [45-47]. We made morphological observations; these approaches are consistent with the previous studies $[47$, 48].

Current studies of OECs and CNS repair suggest that OECs can induce a pathway for olfactory nerve fiber regrowth, migrate through glial scars, and produce phagocyte fragments [17, 18, 49]. OECs may express NGF, BDNF, GDNF, and CNTF as well as their receptors and secrete SCARB2 protein [50-53]. OECs can reduce astrocyte reactivity, promote axon regeneration and enhance functional recovery [20, 26, 54, 55].

Studies have shown that retinal photoreceptor outer segment membrane discs contain rhodopsin and long-chain polyunsaturated fatty acids, whereas the inner segments contain mitochondria, with highoxygen tension making them vulnerable to free radical attack [56]. Strong light may lead to retinal oxidative stress and cause peroxidation of the lipids of the photoreceptor outer segment membrane disc [57]. Absorbing visible light, rhodopsin produces a series of ROS, including superoxide anion radicals $\left(\mathrm{O}^{2-}\right)$, hydroxyl radicals $\left(\mathrm{HO}^{-}\right)$, and $\mathrm{H}_{2} \mathrm{O}_{2}$. These free radicals damage cell membrane lipids, proteins and nucleic acids and induce lipid peroxidation, producing toxic products that can induce apoptosis or necrosis and even dissolve the biofilm. The nicotinamide adenine dinucleotide phosphate (NADPH) oxidase (NOX) family contain enzymes that are known to generate ROS [58], and recent studies show that the NOX family contributes to generation of ROS in the retina $[59,60]$. Nitric oxide (NO), a nitrogen radical, is known to be involved in the injury of light induced retina degeneration [61]. Nitric oxide synthase (NOS) family
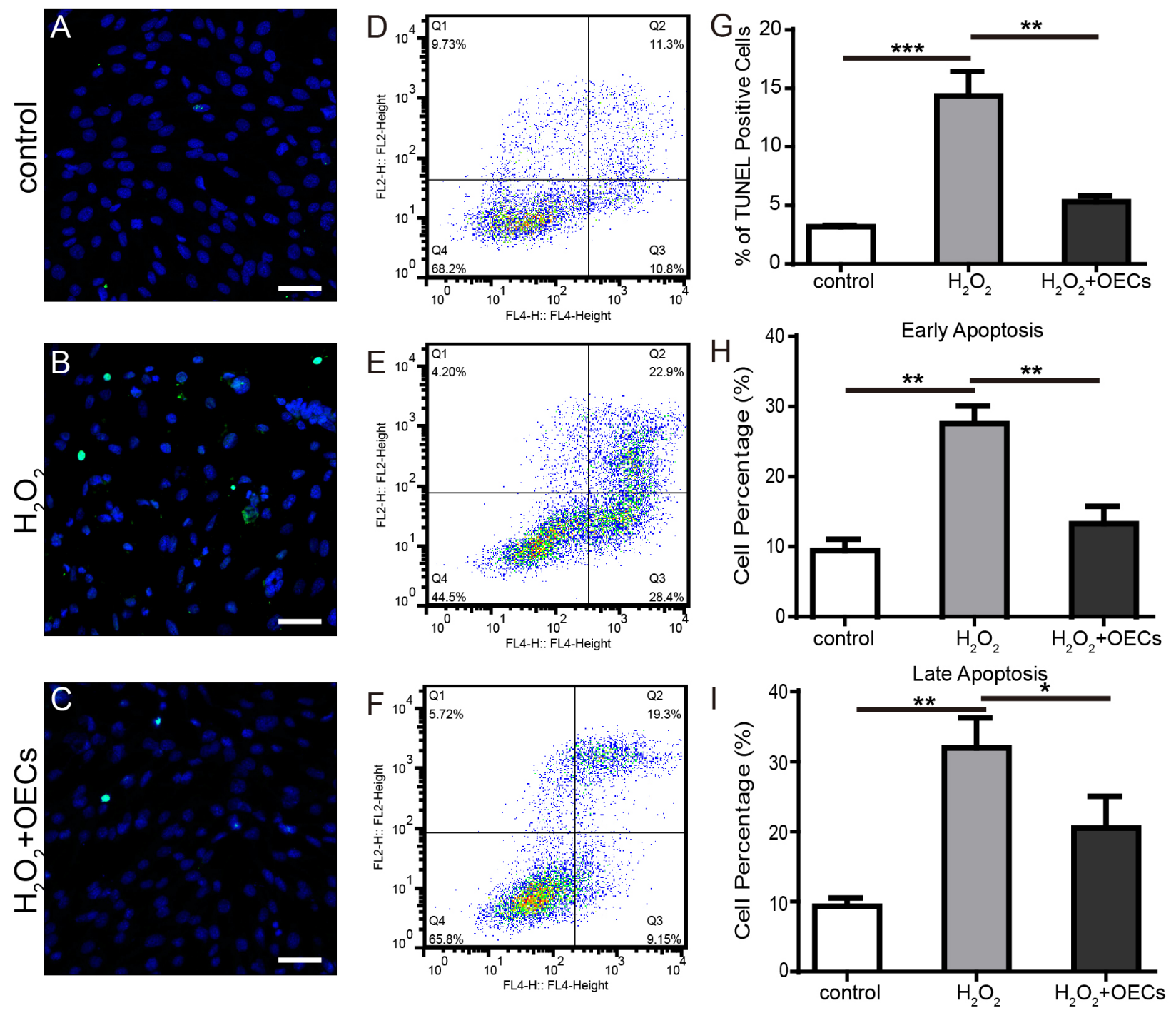

Figure 6: Co-culture with OECs mitigated apoptosis induced by $\mathrm{H}_{2} \mathrm{O}_{2}$. (A-C) Representative images of $661 \mathrm{~W}$ cells stained with TUNEL (green) and DAPI (blue). (D-F) Flow cytometry analysis of apoptosis. (G) Statistics of TUNEL positive cells. (H and I) Statistics of flow cytometry analysis. Scale bars, $50 \mu \mathrm{m} . \mathrm{n}=3,{ }^{*}, p<0.05,{ }^{* *}, p<0.01,{ }^{* * *}, p<0.001$. 

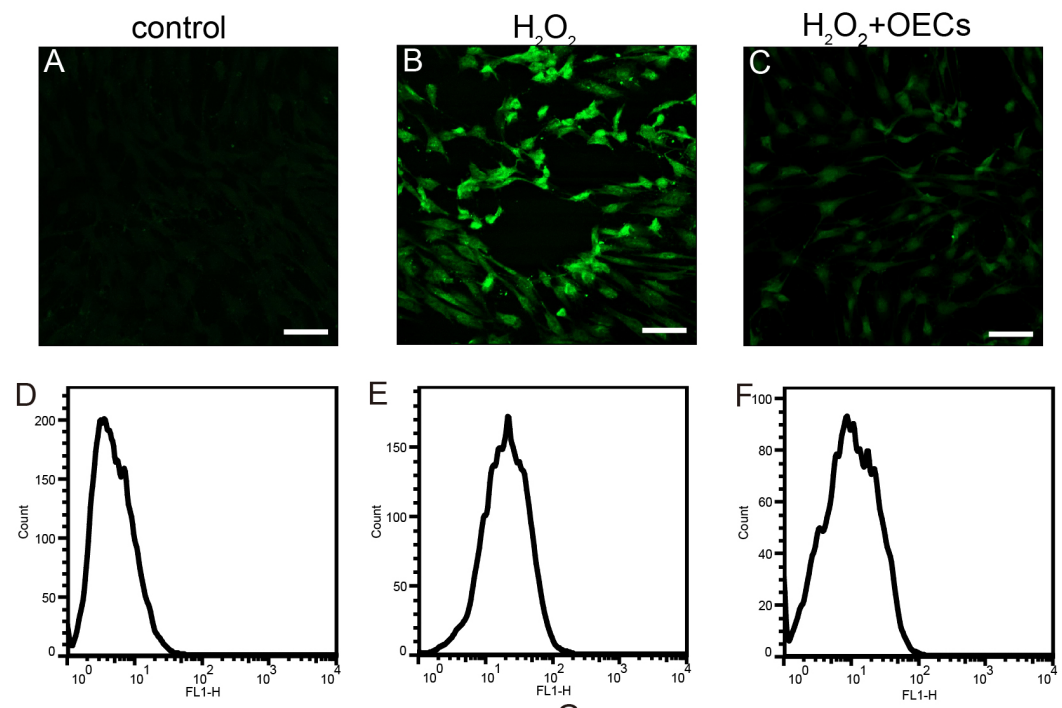

$\mathrm{H}$
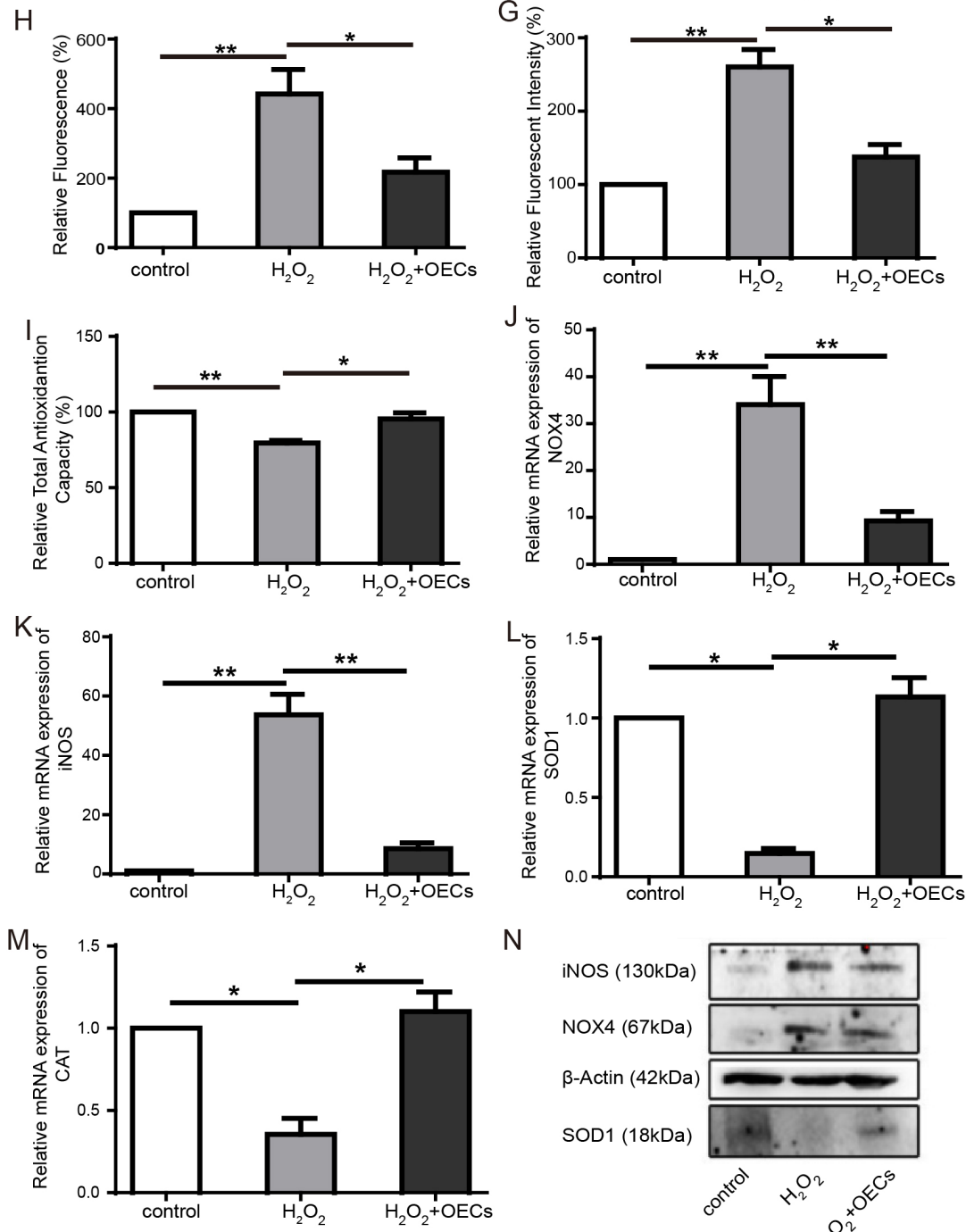

$\mathrm{N}$

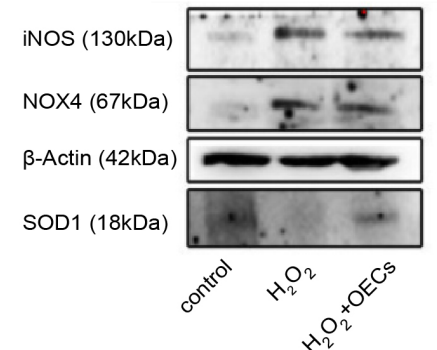

Figure 7: OECs alleviate elevation of intracellular ROS level induced by $\mathrm{H}_{2} \mathrm{O}_{2}$ exposure. (A-C and $\mathrm{H}$ ) Representative images of $661 \mathrm{~W}$ cells stained with ROS (green) and statistics of relative fluorescent intensity of images, $\mathrm{n}=3$. (D-F and $\mathbf{G}$ ) Flow cytometry analysis of intracellular ROS production in $661 \mathrm{~W}$ cells and statistics of relative fluorescent intensity, $n=3$. (I) Statistics of relative total antioxidantion capacity of $661 \mathrm{~W}$ cells. (J-M) Relative mRNA expression of NOX4, iNOS, SOD1, CAT, $\mathrm{n}=5$. (N) Western blot analysis. Scale bars, $50 \mu \mathrm{m} .{ }^{*}, \mathrm{p}<0.05,{ }^{* *}, \mathrm{p}<0.01$. 
Table 1: Designing real-time PCR primers

\begin{tabular}{lll}
\hline Genes(mouse) & Forward primer & Reverse primer \\
\hline$\beta$-Actin & TGAGCTGCGTTTTACACCCT & TTTGGGGGATGTTTGCTCCA \\
NOX4 & GCGTCCTCGGTGGAAACTT & AGTCCCCAGTAGTCTCCTAAG \\
iNOS & AGTCCCCAGTAGTCTCCTAAG & GAACGTAGACCTTGGGTTTGC \\
SOD1 & GAACGTAGACCTTGGGTTTGC & GAACGTAGACCTTGGGTTTGC \\
CAT & CCAAGCAATATGCCCCCTGG & GTAATAGTTGGGGGCACCAC \\
\hline
\end{tabular}

isozymes are known to mediate NO generation [62]. Under physiologic conditions, intracellular protective reductases, such as superoxide dismutase (SOD) and catalase (CAT), may clear ROS; however, when ROS abnormally increases, oxidative and antioxidant systems become imbalanced, leading to damage [5]. Recent studies show that OEC-conditioned medium protected astrocytes from damage by $\mathrm{H}_{2} \mathrm{O}_{2}$ and decreased the ROS and $\mathrm{Ca}^{2+}$ in astrocytes in vitro [63]. OEC-conditioned medium may also promote antioxidant defense, leading to suppression of 6OHDA-induced oxidative damage by enhancing Akt survival signalling [64].

We have demonstrated that transplanting OECs into the subretinal space of rats with light-induced retinal damage reduced this damage and the loss of photoreceptors; it also preserved the ERG a-wave. ERG output might be influenced by injury potentials, but this is unclear [65]. We hypothesized that injury produced by the subretinal injection of PBS might activate retinal regeneration and contribute to rapidly improved ERG amplitudes. However, data showed that ERG amplitudes of the PBS group were not significantly higher than those of the untreated group at 2 and 4 weeks after transplantation. After transplanting OECs, ROS generation was significantly reduced. Grafts of OECs into the subretinal space decreased ROS in light-damaged retinas. The data for in vitro experiments showed that $\mathrm{H}_{2} \mathrm{O}_{2}$ damaged $661 \mathrm{~W}$ cells by increasing NOX4 and iNOS and by the accumulation of intracellular ROS. After being co-cultured with OECs, NOX4 and iNOS expression decreased, SOD1 and CAT increased; and production of intracellular oxidative stress was decreased. Thus, oxidative damage to $661 \mathrm{~W}$ cells was minimized. Improvement of total antioxidant capacity by co-culture with OECs suggested that OECs might reduce ROS by enhancing the antioxidant capacity of $661 \mathrm{~W}$ cells.

These results suggest that oxidative stress might contribute to light-induced retinal damage and that transplanted OECs might scavenge free radicals, increase antioxidant capacity, and inhibit oxidation to protect photoreceptor cells, thus protecting them against lightinduced retinal damage.

In summary, we offer an experimental basis for the use of OECs in light-damaged retinas and expanded the potential value of clinical applications of transplanted OECs in degenerative retinal diseases. Future work should include developing asource of OECs for clinical use and extend their role.

\section{MATERIALS AND METHODS}

\section{Animals}

Adult Long Evans rats (male and femail, 250g) were obtained from the Animal Research Center of the Third Military Medical University. All animal experimental procedures were conducted by adhering to the Association for Research in Vision and Ophthalmology Statement and were subjected to the provisions of the Southwest Hospital Animal Ethics Committee in Chongqing, China. During this study, the rats were housed in an air-conditioned room with dim cyclic light and $a d$ lib food and water.

\section{Model of light-induced retinal damage}

A rat model of light-induced retinal damage was adapted from published methods [41]. Then, after pupils were dilated with atropine sulphate ointment (Shanghai General Pharmaceutical Co., Ltd., China), the eyes of adult Long Evans rats (30 to 35 days old) were exposed to 3800 lux od constant white light for 12,24 , and $36 \mathrm{~h}$. During this exposure, the temperature was kept at $28^{\circ} \mathrm{C}$ and the room was ventilated.

\section{Cell culture}

According to published methods [66, 67], rats were anesthetized with pentobarbital sodium (10mg/ $\mathrm{kg}$, Sigma-Aldrich, St. Louis, MO), and olfactory bulbs were removed under a dissecting microscope. Tissue was isolated from the outer nerve and glomerular layers of olfactory bulbs, cut into small pieces, trypsinized $(0.1 \%$ trypsin for $15 \mathrm{~min}$ at $37^{\circ} \mathrm{C}$ ), the process was stopped by incubation in Dulbecco's Modified Eagle's medium/F-12 culture medium (DMEM/F-12, 1:1 mixture, Hyclone) supplemented with $10 \%$ fetal bovine serum (FBS, Gibco, Waltham, MA) and a mixture of penicillin and 
streptomycin. Cells were plated on uncoated $35-\mathrm{mm}$ dishes two times, each for $24 \mathrm{~h}$ at $37^{\circ} \mathrm{C}$ in a humidified atmosphere containing 5\% $\mathrm{CO}_{2}$. Nonadhesive cells were collected and plated onto 35 dishes coated with polyD-lysine (PDL, Sigma-Aldrich, St. Louis, MO), and cultured with DMEM/F-12, containing 10\% FBS and $1 \%$ PS. The culture medium was changed every 3 days. After being cultured for 2 weeks, cells were collected for immunohistochemistry, transplantation, and co-culture experiments. In the following co-culture experiment, $5 \times 10^{4}$ OECs were seeded per Transwell chamber.

The $661 \mathrm{~W}$ cells were a gift from Dr Yan Luo [68]. Cells were grown in DMEM (Gibco, Waltham, MA) with $10 \% \mathrm{FBS}$ at $37^{\circ} \mathrm{C}$ in a humidified atmosphere containing $5 \% \mathrm{CO}_{2}$. For the assays, cells were divided into three groups: control, $\mathrm{H}_{2} \mathrm{O}_{2-}$ induced, and $\mathrm{OEC}$ co-culture groups. In each group, $5 \times 10^{4}$ cells were seeded per well on a 24 -well plate. After being cultured for $24 \mathrm{~h}$, cells in the model group were treated with $0.5 \mathrm{mM} \mathrm{H}_{2} \mathrm{O}_{2}$ for 30 min, and then co-cultured with OECs for an additional 24 $\mathrm{h}$ in Transwell chambers.

\section{Cell transplantation}

Rats with retinal damage were used for cell transplantation according to published protocols [38, 40, 69]. One day post 24-h continuous light-induced damage, subretinal injection surgery was performed immediately after an ERG recording. Before surgery, OECs were dissociated into suspension and then labeled with CellTracker CM-DiI( $2 \mu \mathrm{g} / \mathrm{ml}$, Invitrogen, Waltham, MA). Cells were washed twice with PBS and then resuspended in PBS. Under an operating microscope, keratonyxis was performed with a 30 -gauge syringe needle to reduce intraocular pressure by increasing the aqueous humour outflow. After penetrating the sclera and choroid, $3 \mu \mathrm{l}$ of a suspension of labeled OECs $\left(1 \times 10^{5}\right.$ cells/ $\left.\mu \mathrm{l}\right)$ were slowly injected into the subretinal space of the temporal retina using a $10-\mu 1$ micro-syringe. Rats in the PBS group were injected with $3 \mu \mathrm{l}$ PBS.

\section{ERG test}

ERGs were recorded 1 day before and 1 day after light-induced damage and at 2, 4, and 8 weeks after retinal cell transplantation. According to published methods $[40,70]$, rats were anesthetized with amine $(100 \mathrm{mg} /$ $\mathrm{kg}$ ) and xylazine $(12 \mathrm{mg} / \mathrm{kg})$ under $\mathrm{dim}$ red light after dark adaptation for $12 \mathrm{~h}$. Rat pupils were then dilated with phenylephrine eye drops (Santen Pharmaceutical Co., Ltd., Japan). Corneal ERG responses were recorded from both eyes simultaneously with gold wire loops. Carboxymethylcellulose sodium eye drops (Allergan, Ireland) were frequently applied to the cornea to prevent dehydration and to allow electrical contact with the recording electrode. Two needle electrodes inserted under the outer layer served as the reference electrodes, whereas the other electrode placed in the tail served as a "ground". Amplification was at a $0.1-500 \mathrm{~Hz}$ band pass without notch filtering, and stimulus presentation and data acquisition were provided using a RETIscan system (Roland, Germany).

\section{H\&E staining}

Rats were anesthetized with tribromoethanol (1 mg/ kg; Sigma-Aldrich, St. Louis, MO) and perfused with $4 \%$ paraformaldehyde (PFA) as previously described $[70,71]$. Eyes were then isolated from their orbits, and the anterior segments were carefully removed. The eye cups were then fixed in 4\% PFA for $1 \mathrm{~h}$ and then removed into $30 \%$ sucrose overnight. Eyes were frozen in OCT compound (Sakura, Torrance, CA) and cut into $10-\mu \mathrm{m}$ thick segments; slides were stained with H\&E and were examined with a microscope.

\section{Immunocytochemical staining}

To identify cultured cells, rabbit anti-S100 antibody (1:500, Sigma-Aldrich, St. Louis, MO) was used as a cell marker to identify OECs and mouse anti-fibronectin antibody (1:500, Abcam, Cambridge, MA) was used as a cell marker to identify ONFs according to our previous protocol $[38,67]$. Coverslips were washed three times with PBS, incubated with secondary antibody goat anti-mouse IgG-488 and goat anti-rabbit IgG-568 (Invitrogen, Waltham, MA, USA) for $1 \mathrm{~h}$ at room temperature and counterstained with DAPI dihydrochloride (Beyotime, China) for $5 \mathrm{~min}$ at room temperature. After being washed three times, the coverslips were mounted with Antifade Mounting Medium (Beyotime, China).

ONL thickness was measured in the horizontal position based on previously established protocels [47, 72, 73]. Cell nuclei were counter-stained with DAPI dihydrochloride, and the thicknesses of the ONLs from the optic nerve head were measured at $0.5 \mathrm{~mm}$ intervals using the ImageJ program (developed by Wayne Rasband, NIH, Bethesda, MD; available at http://rsb.info.nih.gov/ ij/index.html).

For Ki67 staining, the $661 \mathrm{~W}$ cells were fixed with $4 \% \mathrm{PFA}$ and permeabilized with $0.5 \%$ Triton X-100. After blocking with a $3 \%$ bovine serum albumin solution, the cells were incubated with anti-Ki67 antibody (1:500, Abcam, Cambridge, MA) overnight at $4^{\circ} \mathrm{C}$. Then the cells were incubated with secondary antibody, goat antirabbit IgG-568, for $1 \mathrm{~h}$ at room temperature and stained with DAPI dihydrochloride. Images were captured with a fluorescence microscope.

\section{Immunofluorescent staining of ROS in the retina}

Retinal intracellular ROS generation was analyzed with a DCFH-DA probe using afrozen sections reactive 
oxygen species testing kit (Genmed Scientifics Inc., Wilmington, DE). Frozen sections were air dried at room temperature for $15 \mathrm{~min}$ and washed with Reagent A. All sections were then incubated with dye containing $1 \%$ Reagent $\mathrm{B}$ and $99 \%$ Reagent $\mathrm{C}$ for $20 \mathrm{~min}$ at $37^{\circ} \mathrm{C}$ and then washed with Reagent A. After staining with DAPI dihydrochloride, sections were washed with PBS, cover slipped with antifade mounting medium, and then counted under a fluorescent microscope.

\section{CCK-8 assay}

The cell viability of $661 \mathrm{~W}$ cells was measured using a cell counting kit-8 assay (CCK-8, Dojindo, Japan). The $661 \mathrm{~W}$ cells were plated on 24 -wells plates $\left(5 \times 10^{4}\right.$ cells/ well), and the OECs were plated in Transwell ( $5 \times 10^{4}$ cells). After being cultured for 1 day, $661 \mathrm{~W}$ cells were treated with $0.5 \mathrm{mM} \mathrm{H}_{2} \mathrm{O}_{2}$ for $30 \mathrm{~min}$ and then co-cultured with OECs for $24 \mathrm{~h}$ by using in a Transwell chamber. Cells were washed with PBS three times, then $300 \mu$ fresh DMEM with $30 \mu \mathrm{l}$ CCK-8 solution was added to the 24 -well plates. After incubation at $37^{\circ} \mathrm{C}$ for $1 \mathrm{~h}$, the absorbance was measured at $450 \mathrm{~nm}$ and $570 \mathrm{~nm}$ using a microplate reader (Varioskan Flash, Thermo-Fisher, Waltham, MA).

\section{EdU staining of $661 \mathrm{~W}$ cells}

According to the manufacturer's instructions for the Cell-LightTM EdU staining kit (Ribobio, China), cells were treated with $50 \mu \mathrm{M} / \mathrm{L}$ EdU for $2 \mathrm{~h}$ at $37^{\circ} \mathrm{C}$. After fixing with 4\% PFA for $20 \mathrm{~min}$ and treatment with $0.5 \%$ Triton X-100 for $10 \mathrm{~min}$ at room temperature, cells were incubated with Apollo reaction reagent for $30 \mathrm{~min}$ at $37^{\circ}$ Cand counterstained with DAPI dihydrochloride. The images were captured with a fluorescence microscope.

\section{Apoptosis}

Apoptosis of $661 \mathrm{~W}$ cells was measured using the TUNEL assay, an in situ cell death detection kit (Roche, Nutley, NJ) and flow cytometry using an apoptosis detection kit (BD, Franklin Lakes, NJ). Cells were fixed, permeabilized, and incubated with TUNEL reaction mixture at $37^{\circ} \mathrm{C}$ for $1 \mathrm{~h}$ and stained with DAPI dihydrochloride for 5 min at room temperature. Then, the cells were observed and counted under a fluorescent microscope.

For apoptosis assessment, the $661 \mathrm{~W}$ cells were washed with PBS three times and then harvested and resuspended in binding buffer. Cells were incubated with PI and APC-conjugated Annexin V and then analysed by flow cytometry (BD FACS Calibur, Franklin Lakes, NJ).

\section{ROS production of $661 \mathrm{~W}$ cells}

To measure ROS production, cells were incubated with DCFH-DA (Sigma-Aldrich, St. Louis, MO) at $37^{\circ} \mathrm{C}$ for $30 \mathrm{~min}$ as described previously. After washing three times with PBS, ROS was measured with fluorescence microscope and flow cytometry.

\section{Total antioxidant capacity}

The total antioxidant capacity of cells was measured by the ferric reducing ability of plasma (FRAP) method using a Total Antioxidant Capacity Assay Kit (Beyotime, China). Briefly, cells were collected, homogenized and incubated with FRAP solution at $37^{\circ} \mathrm{C}$ for $5 \mathrm{~min}$. The absorbance was measured at $595 \mathrm{~nm}$ using a microplate reader (Varioskan Flash, Thermo-Fisher, Waltham, MA).

\section{Real-time PCR}

After treatment with $\mathrm{H}_{2} \mathrm{O}_{2}$ and co-culturing with OECs, 661W cells from three independent experiments were collected for subsequent real-time PCR, as previously described [70]. In brief, after total RNAs was isolated with Trizol reagent (Takara, Japan), cDNA was synthesized in $20 \mu \mathrm{l}$ of reaction mixture from $2 \mu \mathrm{g}$ of total RNA using a PrimeScript RT reagent Kit (Takara, Japan) according to the manufacturer's instructions. The primers used in the present study indicated in Table 1 and designed using IDT Scitools. Real-time PCR was performed in a Bio-Rad 5-Color System (Bio-Rad Laboratories, Hercules, CA) with a SYBR Premix Ex Tag (Tli RNaseH Plus) kit (Takara, Japan). The results were analyzed using the $2(-\Delta \Delta$ $\mathrm{C}(\mathrm{T})$ ) method.

\section{Western blots}

According to our previous protocol [70], 661W cells were lysed in ice-cold RIPA buffer (Beyotime, China) and centrifuged at $12,000 \mathrm{xg}$ at $4^{\circ} \mathrm{C}$ for $10 \mathrm{~min}$, and the protein was measured using a BCA protein assay kit

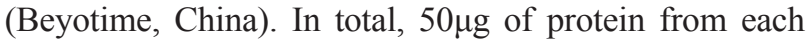
group was separated via SDS-PAGE and transferred to PVDF membranes. Blots were blocked with 5\% nonfat milk in Tris-buffered saline/Tween for $1 \mathrm{~h}$ at room temperature. Then membranes were incubated with primary antibodies (NOX4, Abcam, Cambridge, MA; iNOS, Santa Cruz, Dallas, TX; SOD1, Bioworld, China) overnight at $4{ }^{\circ} \mathrm{C}$. After incubation with peroxidase-conjugated immunoglobulin G (1:2,000; Santa Cruz, Dallas, TX) as secondary antibodies, the membranes were scanned using a ChemiDoc MP ImagingSystem (Bio-Rad Laboratories, Hercules, CA).

\section{Statistical analysis}

Data are presented as mean \pm SEM for at least three independent experiments. Data were evaluated using oneway ANOVA followed by a Tukey's test using SPSS 13.0 software for comparing the means between groups $(p<0.05$ was considered to be statistically significant). 


\section{Author contributions}

Z.Q.Y. and H.W.X. conceived the study; L.Y.X., Y.X.Z., Q.Y.L., Y.J.L. and Z.Y.L. performed the experiments; Z.Q.Y., H.W.X. and L.Y.X. wrote the manuscript. All authors reviewed and edited the manuscript.

\section{ACKNOWLEDGMENTS AND FUNDING}

We are grateful to Dr. Yaocheng Li for kindly help. This work was supported by the National Basic Research Program of China (973 Program, 2013CB967002, 2013CB967001).

\section{CONFLICTS OF INTEREST}

The authors declare that they have no conflicts of interest.

\section{Compliance with Ethical Standards}

All of the animal experimental procedures were subjected to the provisions of the Southwest Hospital Animal Ethics Committee in Chongqing, China.

\section{REFERENCES}

1. Noell WK, Walker VS, Kang BS, Berman S. Retinal damage by light in rats. Invest Ophthalmol. 1966; 5:450-73.

2. Organisciak DT, Vaughan DK. Retinal light damage: mechanisms and protection. Prog Retin Eye Res. 2010; 29:113-34. https://doi.org/10.1016/j.preteyeres.2009.11.004.

3. Youssef PN, Sheibani N, Albert DM. Retinal light toxicity. Eye (Lond). 2011; 25:1-14. https://doi.org/10.1038/ eye.2010.149.

4. Li J, Edward DP, Lam TT, Tso MO. Amelioration of retinal photic injury by a combination of flunarizine and dimethylthiourea. Exp Eye Res. 1993; 56:71-8.

5. Wenzel A, Grimm C, Samardzija M, Reme CE. Molecular mechanisms of light-induced photoreceptor apoptosis and neuroprotection for retinal degeneration. Prog Retin Eye Res. 2005; 24:275-306. https://doi.org/10.1016/j. preteyeres.2004.08.002.

6. Ito $\mathrm{Y}$, Nakamura $\mathrm{S}$, Tanaka $\mathrm{H}$, Tsuruma $\mathrm{K}$, Shimazawa M, Araie M, Hara H. Lomerizine, a $\mathrm{Ca} 2+$ channel blocker, protects against neuronal degeneration within the visual center of the brain after retinal damage in mice. CNS Neurosci Ther. 2010; 16:103-14. https://doi. org/10.1111/j.1755-5949.2009.00081.x.

7. Forkwa TK, Neumann ID, Tamm ER, Ohlmann A, Reber SO. Short-term psychosocial stress protects photoreceptors from damage via corticosterone-mediated activation of the AKT pathway. Exp Neurol. 2014; 252:28-36. https://doi. org/10.1016/j.expneurol.2013.11.016.
8. Inoue Y, Shimazawa M, Nakamura S, Imamura T, Sugitani S, Tsuruma K, Hara H. Protective effects of placental growth factor on retinal neuronal cell damage. J Neurosci Res. 2014; 92:329-37. https://doi.org/10.1002/jnr.23316.

9. Iuvone PM, Boatright $\mathrm{JH}$, Tosini $\mathrm{G}$, Ye $\mathrm{K}$. $\mathrm{N}$-acetylserotonin: circadian activation of the BDNF receptor and neuroprotection in the retina and brain. Adv Exp Med Biol. 2014; 801:765-71. https://doi. org/10.1007/978-1-4614-3209-8_96.

10. Murase H, Shimazawa M, Kakino M, Ichihara K, Tsuruma $\mathrm{K}$, Hara $\mathrm{H}$. The effects of Brazilian green propolis against excessive light-induced cell damage in retina and fibroblast cells. Evid Based Complement Alternat Med. 2013; 2013:238279. https://doi.org/10.1155/2013/238279.

11. Ojino K, Shimazawa M, Ohno Y, Otsuka T, Tsuruma K, Hara H. Protective effect of SUN N8075, a free radical scavenger, against excessive light-induced retinal damage in mice. Biol Pharm Bull. 2014; 37:424-30.

12. Li Y, Li D, Raisman G. Interaction of olfactory ensheathing cells with astrocytes may be the key to repair of tract injuries in the spinal cord: the 'pathway hypothesis'. J Neurocytol. 2005; 34:343-51. https://doi.org/10.1007/ s11068-005-8361-1.

13. Wewetzer K, Verdu E, Angelov DN, Navarro X. Olfactory ensheathing glia and Schwann cells: two of a kind? Cell Tissue Res. 2002; 309:337-45. https://doi.org/10.1007/ s00441-002-0607-y.

14. Cao L, Liu L, Chen ZY, Wang LM, Ye JL, Qiu HY, Lu CL, $\mathrm{He}$ C. Olfactory ensheathing cells genetically modified to secrete GDNF to promote spinal cord repair. Brain. 2004; 127:535-49. https://doi.org/10.1093/brain/awh072.

15. Kocsis JD, Lankford KL, Sasaki M, Radtke C. Unique in vivo properties of olfactory ensheathing cells that may contribute to neural repair and protection following spinal cord injury. Neurosci Lett. 2009; 456:137-42. https://doi. org/10.1016/j.neulet.2008.08.093.

16. Pellitteri R, Spatuzza M, Russo A, Zaccheo D, Stanzani S. Olfactory ensheathing cells represent an optimal substrate for hippocampal neurons: an in vitro study. Int $\mathrm{J}$ Dev Neurosci. 2009; 27:453-8. https://doi.org/10.1016/j. ijdevneu.2009.05.001.

17. Wewetzer K, Kern N, Ebel C, Radtke C, Brandes G. Phagocytosis of $\mathrm{O} 4+$ axonal fragments in vitro by $\mathrm{p} 75$ neonatal rat olfactory ensheathing cells. Glia. 2005; 49:57787. https://doi.org/10.1002/glia.20149.

18. Li Y, Field PM, Raisman G. Repair of adult rat corticospinal tract by transplants of olfactory ensheathing cells. Science. 1997; 277:2000-2.

19. Li Y, Field PM, Raisman G. Regeneration of adult rat corticospinal axons induced by transplanted olfactory ensheathing cells. J Neurosci. 1998; 18:10514-24.

20. Ramon-Cueto A, Cordero MI, Santos-Benito FF, Avila J. Functional recovery of paraplegic rats and motor axon 
regeneration in their spinal cords by olfactory ensheathing glia. Neuron. 2000; 25:425-35.

21. Lu J, Feron F, Ho SM, Mackay-Sim A, Waite PM. Transplantation of nasal olfactory tissue promotes partial recovery in paraplegic adult rats. Brain Res. 2001; 889:344-57.

22. Lu J, Feron F, Mackay-Sim A, Waite PM. Olfactory ensheathing cells promote locomotor recovery after delayed transplantation into transected spinal cord. Brain. 2002; 125:14-21.

23. Plant GW, Christensen CL, Oudega M, Bunge MB. Delayed transplantation of olfactory ensheathing glia promotes sparing/regeneration of supraspinal axons in the contused adult rat spinal cord. J Neurotrauma. 2003; 20:1-16. https:// doi.org/10.1089/08977150360517146.

24. Kubasak MD, Jindrich DL, Zhong H, Takeoka A, McFarland KC, Munoz-Quiles C, Roy RR, Edgerton VR, Ramon-Cueto A, Phelps PE. OEG implantation and step training enhance hindlimb-stepping ability in adult spinal transected rats. Brain. 2008; 131:264-76. https://doi. org/10.1093/brain/awm267.

25. Barbour HR, Plant CD, Harvey AR, Plant GW. Tissue sparing, behavioral recovery, supraspinal axonal sparing/ regeneration following sub-acute glial transplantation in a model of spinal cord contusion. BMC Neurosci. 2013; 14:106. https://doi.org/10.1186/1471-2202-14-106.

26. Mayeur A, Duclos C, Honore A, Gauberti M, Drouot L, do Rego JC, Bon-Mardion N, Jean L, Verin E, Emery E, Lemarchant S, Vivien D, Boyer O, et al. Potential of olfactory ensheathing cells from different sources for spinal cord repair. PLoS One. 2013; 8:e62860. https://doi. org/10.1371/journal.pone.0062860.

27. Witheford M, Westendorf K, Roskams AJ. Olfactory ensheathing cells promote corticospinal axonal outgrowth by a L1 CAM-dependent mechanism. Glia. 2013; 61:187389. https://doi.org/10.1002/glia.22564.

28. Khankan RR, Wanner IB, Phelps PE. Olfactory ensheathing cell-neurite alignment enhances neurite outgrowth in scarlike cultures. Exp Neurol. 2015; 269:93-101. https://doi. org/10.1016/j.expneurol.2015.03.025.

29. Ruitenberg MJ, Plant GW, Hamers FP, Wortel J, Blits B, Dijkhuizen PA, Gispen WH, Boer GJ, Verhaagen J. Ex vivo adenoviral vector-mediated neurotrophin gene transfer to olfactory ensheathing glia: effects on rubrospinal tract regeneration, lesion size, and functional recovery after implantation in the injured rat spinal cord. J Neurosci. 2003; 23:7045-58.

30. Pastrana E, Moreno-Flores MT, Avila J, Wandosell F, Minichiello L, Diaz-Nido J. BDNF production by olfactory ensheathing cells contributes to axonal regeneration of cultured adult CNS neurons. Neurochem Int. 2007; 50:4918. https://doi.org/10.1016/j.neuint.2006.10.004.

31. Takeoka A, Kubasak MD, Zhong H, Roy RR, Phelps PE. Serotonergic innervation of the caudal spinal stump in rats after complete spinal transection: effect of olfactory ensheathing glia. J Comp Neurol. 2009; 515:664-76. https:// doi.org/10.1002/cne.22080.

32. Rao Y, Zhu W, Guo Y, Jia C, Qi R, Qiao R, Cao D, Zhang H, Cui Z, Yang L, Wang Y. Long-term outcome of olfactory ensheathing cell transplantation in six patients with chronic complete spinal cord injury. Cell Transplant. 2013; 22: S21-5. https://doi. org/10.3727/096368913X672127.

33. Tabakow P, Jarmundowicz W, Czapiga B, Fortuna W, Miedzybrodzki R, Czyz M, Huber J, Szarek D, Okurowski S, Szewczyk P, Gorski A, Raisman G. Transplantation of autologous olfactory ensheathing cells in complete human spinal cord injury. Cell Transplant. 2013; 22:1591-612. https://doi.org/10.3727/096368912X663532.

34. Tabakow P, Raisman G, Fortuna W, Czyz M, Huber J, Li D, Szewczyk P, Okurowski S, Miedzybrodzki R, Czapiga B, Salomon B, Halon A, Li Y, et al. Functional regeneration of supraspinal connections in a patient with transected spinal cord following transplantation of bulbar olfactory ensheathing cells with peripheral nerve bridging. Cell Transplant. 2014; 23:1631-55. https://doi. org/10.3727/096368914X685131.

35. Li Y, Sauve Y, Li D, Lund RD, Raisman G. Transplanted olfactory ensheathing cells promote regeneration of cut adult rat optic nerve axons. J Neurosci. 2003; 23:7783-8.

36. Li Y, Li D, Khaw PT, Raisman G. Transplanted olfactory ensheathing cells incorporated into the optic nerve head ensheathe retinal ganglion cell axons: possible relevance to glaucoma. Neurosci Lett. 2008; 440:251-4. https://doi. org/10.1016/j.neulet.2008.05.085.

37. Leaver SG, Harvey AR, Plant GW. Adult olfactory ensheathing glia promote the long-distance growth of adult retinal ganglion cell neurites in vitro. Glia. 2006; 53:467-76. https://doi.org/10.1002/glia.20311.

38. Huo SJ, Li Y, Raisman G, Yin ZQ. Transplanted olfactory ensheathing cells reduce the gliotic injury response of Muller cells in a rat model of retinitis pigmentosa. Brain Res. 2011; 1382:238-44. https://doi.org/10.1016/j. brainres.2010.12.079.

39. Xie J, Huo S, Li Y, Dai J, Xu H, Yin ZQ. Olfactory ensheathing cells inhibit gliosis in retinal degeneration by down-regulation of the Muller cell Notch signaling pathway. Cell Transplant. 2017; 26:967-82. https://doi. org/10.3727/096368917X694994.

40. Huo SJ, Li YC, Xie J, Li Y, Raisman G, Zeng YX, He JR, Weng CH, Yin ZQ. Transplanted olfactory ensheathing cells reduce retinal degeneration in Royal College of Surgeons rats. Curr Eye Res. 2012; 37:749-58. https://doi.org/10.310 9/02713683.2012.697972.

41. Bowers F, Valter K, Chan S, Walsh N, Maslim J, Stone J. Effects of oxygen and bFGF on the vulnerability of photoreceptors to light damage. Invest Ophthalmol Vis Sci. 2001; 42:804-15. 
42. Fletcher AE, Bentham GC, Agnew M, Young IS, Augood C, Chakravarthy U, de Jong PT, Rahu M, Seland J, Soubrane G, Tomazzoli L, Topouzis F, Vingerling JR, et al. Sunlight exposure, antioxidants, and age-related macular degeneration. Arch Ophthalmol. 2008; 126:1396-403. https://doi.org/10.1001/archopht.126.10.1396.

43. Marc RE, Jones BW, Watt CB, Vazquez-Chona F, Vaughan DK, Organisciak DT. Extreme retinal remodeling triggered by light damage: implications for age related macular degeneration. Mol Vis. 2008; 14:782-806.

44. Tan JS, Wang JJ, Flood V, Rochtchina E, Smith W, Mitchell P. Dietary antioxidants and the long-term incidence of age-related macular degeneration. Ophthalmology. 2008; 115:334-41. https://doi.org/10.1016/j.ophtha.2007.03.083.

45. Organisciak DT, Darrow RA, Barsalou L, Darrow RM, Lininger LA. Light-induced damage in the retina: differential effects of dimethylthiourea on photoreceptor survival, apoptosis and DNA oxidation. Photochem Photobiol. 1999; 70:261-8.

46. Ranchon I, LaVail MM, Kotake Y, Anderson RE. Free radical trap phenyl-N-tert-butylnitrone protects against light damage but does not rescue $\mathrm{P} 23 \mathrm{H}$ and $\mathrm{S} 334$ ter rhodopsin transgenic rats from inherited retinal degeneration. J Neurosci. 2003; 23:6050-7.

47. Tian L, Zhang L, Xia F, An J, Sugita Y, Zhang Z. Hydrogenrich saline ameliorates the retina against light-induced damage in rats. Med Gas Res. 2013; 3:19. https://doi. org/10.1186/2045-9912-3-19.

48. Tanito M, Li F, Elliott MH, Dittmar M, Anderson RE. Protective effect of TEMPOL derivatives against lightinduced retinal damage in rats. Invest Ophthalmol Vis Sci. 2007; 48:1900-5. https://doi.org/10.1167/iovs.06-1057.

49. Li Y, Field PM, Raisman G. Olfactory ensheathing cells and olfactory nerve fibroblasts maintain continuous open channels for regrowth of olfactory nerve fibres. Glia. 2005; 52:245-51. https://doi.org/10.1002/glia.20241.

50. Wewetzer K, Grothe C, Claus P. In vitro expression and regulation of ciliary neurotrophic factor and its alpha receptor subunit in neonatal rat olfactory ensheathing cells. Neurosci Lett. 2001; 306:165-8.

51. Woodhall E, West AK, Chuah MI. Cultured olfactory ensheathing cells express nerve growth factor, brain-derived neurotrophic factor, glia cell line-derived neurotrophic factor and their receptors. Brain Res Mol Brain Res. 2001; 88:203-13.

52. Lipson AC, Widenfalk J, Lindqvist E, Ebendal T, Olson L. Neurotrophic properties of olfactory ensheathing glia. Exp Neurol. 2003; 180:167-71.

53. Roet KC, Franssen EH, de Bree FM, Essing AH, Zijlstra SJ, Fagoe ND, Eggink HM, Eggers R, Smit AB, van Kesteren RE, Verhaagen J. A multilevel screening strategy defines a molecular fingerprint of proregenerative olfactory ensheathing cells and identifies SCARB2, a protein that improves regenerative sprouting of injured sensory spinal axons. J Neurosci. 2013; 33:11116-35. https://doi. org/10.1523/JNEUROSCI.1002-13.2013.

54. Ramon-Cueto A, Plant GW, Avila J, Bunge MB. Longdistance axonal regeneration in the transected adult rat spinal cord is promoted by olfactory ensheathing glia transplants. J Neurosci. 1998; 18:3803-15.

55. Richter MW, Fletcher PA, Liu J, Tetzlaff W, Roskams AJ. Lamina propria and olfactory bulb ensheathing cells exhibit differential integration and migration and promote differential axon sprouting in the lesioned spinal cord. J Neurosci. 2005; 25:10700-11. https://doi.org/10.1523/ JNEUROSCI.3632-05.2005.

56. Birol G, Wang S, Budzynski E, Wangsa-Wirawan ND, Linsenmeier RA. Oxygen distribution and consumption in the macaque retina. Am J Physiol Heart Circ Physiol. 2007; 293:H1696-704. https://doi.org/10.1152/ ajpheart.00221.2007.

57. Organisciak DT, Darrow RM, Barsalou L, Kutty RK, Wiggert B. Susceptibility to retinal light damage in transgenic rats with rhodopsin mutations. Invest Ophthalmol Vis Sci. 2003; 44:486-92.

58. Bedard K, Krause KH. The NOX family of ROS-generating NADPH oxidases: physiology and pathophysiology. Physiol Rev. 2007; 87:245-313. https://doi.org/10.1152/ physrev.00044.2005.

59. Usui S, Oveson BC, Lee SY, Jo YJ, Yoshida T, Miki A, Miki K, Iwase T, Lu L, Campochiaro PA. NADPH oxidase plays a central role in cone cell death in retinitis pigmentosa. J Neurochem. 2009; 110:1028-37. https://doi. org/10.1111/j.1471-4159.2009.06195.x.

60. Bhatt L, Groeger G, McDermott K, Cotter TG. Rod and cone photoreceptor cells produce ROS in response to stress in a live retinal explant system. Mol Vis. 2010; 16:283-93.

61. Palamalai V, Darrow RM, Organisciak DT, Miyagi M. Light-induced changes in protein nitration in photoreceptor rod outer segments. Mol Vis. 2006; 12:1543-51.

62. Stuehr DJ, Griffith OW. Mammalian nitric oxide synthases. Adv Enzymol Relat Areas Mol Biol. 1992; 65:287-346.

63. Liu J, Qiu J, Xiong Y, Liu Z, Gao J. The mitochondrial protective mechanism of olfactory ensheathing cells conditioned medium protects against $\mathrm{H} 2 \mathrm{O} 2$-induced injury in astrocytes. Neurosci Lett. 2013; 555:91-6. https://doi. org/10.1016/j.neulet.2013.09.011.

64. Shukla A, Mohapatra TM, Parmar D, Seth K. Neuroprotective potentials of neurotrophin rich olfactory ensheathing cell's conditioned media against 6OHDAinduced oxidative damage. Free Radic Res. 2014; 48:56071. https://doi.org/10.3109/10715762.2014.894636.

65. Timmers AM, Zhang H, Squitieri A, Gonzalez-Pola C. Subretinal injections in rodent eyes: effects on electrophysiology and histology of rat retina. Mol Vis. 2001; 7:131-7.

66. Cao L, Su Z, Zhou Q, Lv B, Liu X, Jiao L, Li Z, Zhu Y, Huang Z, Huang A, He C. Glial cell line-derived 
neurotrophic factor promotes olfactory ensheathing cells migration. Glia. 2006; 54:536-44. https://doi.org/10.1002/ glia.20403.

67. Wang YH, Li YC, Huo SJ, Yin ZQ. Alpha-crystallin promotes rat olfactory ensheathing cells survival and proliferation through regulation of $\mathrm{PI} 3 \mathrm{~K} / \mathrm{Akt} / \mathrm{mTOR}$ signaling pathways. Neurosci Lett. 2012; 531:170-5. https:// doi.org/10.1016/j.neulet.2012.10.057.

68. Ma W, Zhu X, Ding X, Li T, Hu Y, Hu X, Yuan L, Lei L, $\mathrm{Hu}$ A, Luo Y, Tang S. Protective effects of SS31 on tBHP induced oxidative damage in $661 \mathrm{~W}$ cells. Mol Med Rep. 2015; 12:5026-34. https://doi.org/10.3892/mmr.2015.4055.

69. Jian Q, Li Y, Yin ZQ. Rat BMSCs initiate retinal endogenous repair through NGF/TrkA signaling. Exp Eye Res. 2015; 132:34-47. https://doi.org/10.1016/j. exer.2015.01.008.

70. Tao Z, Dai J, He J, Li C, Li Y, Yin ZQ. The influence of $\mathrm{NaIO}(3)$-induced retinal degeneration on intra-retinal layer and the changes of expression profile/morphology of
DA-ACs and mRGCS. Mol Neurobiol. 2013; 47:241-60. https://doi.org/10.1007/s12035-012-8366-6.

71. Jian Q, Tao Z, Li Y, Yin ZQ. Acute retinal injury and the relationship between nerve growth factor, Notch1 transcription and short-lived dedifferentiation transient changes of mammalian Muller cells. Vision Res. 2015; 110:107-17. https://doi.org/10.1016/j.visres.2015.01.030.

72. Ni YQ, Xu GZ, Hu WZ, Shi L, Qin YW, Da CD. Neuroprotective effects of naloxone against light-induced photoreceptor degeneration through inhibiting retinal microglial activation. Invest Opthalmol Vis Sci. 2008; 49:2589. https://doi.org/10.1167/iovs.07-1173.

73. Narimatsu T, Ozawa Y, Miyake S, Nagai N, Tsubota K. Angiotensin II type 1 receptor blockade suppresses lightinduced neural damage in the mouse retina. Free Radic Biol Med. 2014; 71:176-85. https://doi.org/10.1016/j. freeradbiomed.2014.03.020. 